$10-2016$

\title{
Book Review: The Crime of All Crimes: Towards a Criminology of Genocide
}

Suwita Hani Randhawa

University of Oxford

Follow this and additional works at: https://digitalcommons.usf.edu/gsp

\section{Recommended Citation}

Randhawa, Suwita Hani (2016) "Book Review: The Crime of All Crimes: Towards a Criminology of Genocide," Genocide Studies and Prevention: An International Journal: Vol. 10: Iss. 2: 141-143.

DOI:

http://dx.doi.org/10.5038/1911-9933.10.2.1414

Available at: https://digitalcommons.usf.edu/gsp/vol10/iss2/14

This Book Review is brought to you for free and open access by the Open Access Journals at Digital Commons @ University of South Florida. It has been accepted for inclusion in Genocide Studies and Prevention: An International Journal by an authorized editor of Digital Commons @ University of South Florida. For more information, please contact digitalcommons@usf.edu. 
Book Review: The Crime of All Crimes: Towards a Criminology of Genocide

Suwita Hani Randhawa

University of Oxford

Oxford, United Kingdom

The Crime of All Crimes: Towards a Criminology of Genocide

Nicole Rafter

New York and London, New York University Press, 2016

320 Pages; Price: $\$ 35.00$ Cloth

Reviewed by Suwita Hani Randhawa

University of Oxford

Contending with a subject that has provoked sustained interest across many disciplines within the social sciences, Nicole Rafter's latest book is an important addition to the ever-expanding field of genocide studies, one which will be appreciated by scholars and students of genocide from, for instance, history, sociology, psychology, law, political science and international relations. That Rafter herself is aware of the attention from diverse audiences that her book might inevitably garner is evident from the skilful way in which she engages with and navigates through the wealth of existing multidisciplinary scholarship and research on genocide throughout her book. This is all the more impressive given that this was Rafter's very first book on genocide, having only taken an interest in genocide in recent years. For those deeply immersed in genocide studies and its evolving conceptual and empirical concerns, Rafter's book successfully speaks to, and builds upon, important work that has already been done in the field, particularly concerning colonial genocides, the gendered nature of genocides, and the micro-level variables that enable and sustains genocides. Meanwhile, for those newly acquainted with genocide studies, the book provides an accessible overview of the key debates and studies that have come to define the field.

Rafter is a criminologist and her book, as its title suggests, is an examination of genocide from a criminological perspective. While criminologists have started to contribute to the study of genocide, this body of scholarship is still, as Rafter points out, relatively small. Rafter's key aim, therefore, is to demonstrate more forcefully how, and to what extent, criminology can contribute towards a better understanding of genocide. Rafter stamps her unique mark in contemporary genocide scholarship by weaving together an overarching framework to wrestle with the phenomenon that is genocide. Capitalizing on criminology's interdisciplinary character, Rafter draws upon ideas from political science, psychology, sociology, and legal philosophy to construct her analytical building blocks. The result is a comprehensive conceptual vocabulary for genocide, one aimed at simultaneously grappling with the macro, meso and micro elements of genocide. In this regard, a number of Rafter's novel conceptual ideas have the prospect of guiding future research on genocide. This includes her idea of "genocidal propensity," which is aimed at predicting which states are more predisposed towards committing genocides, in order to more effectively prevent genocides before they occur; the idea of "hot genocides," which indicates how the intensification of genocide's emotional dynamics mark turning points in genocidal violence; and finally, the idea that "genocidal organizations" create "states of exception," as a tool to mobilize genocidal destruction without fear of consequences.

Rafter's empirical task is ambitious: a comparative study of eight historical cases of genocides, occurring across the world and covering the period between 1900 and 2000. Following a common position embraced by many genocide scholars, she adopts a definition of genocide that goes beyond the one currently enshrined in international law. The destruction of political groupsnotably excluded from the Genocide Convention-is added as a protected group in Rafter's analysis, alongside national, ethnic, racial and religious groups. This allows the genocide of the Herero by the German colonial army, the Armenians by the Ottoman Turks, Polish nationalists by Stalin, Indonesian anti-communists by Suharto's regime, political opponents by Pol Pot's regime, the Mayas by the Guatemalan state, and the Tutsis by the Rwandan Hutus to fall under the scope of her study. This is relatively uncontroversial; what is controversial, however, is her inclusion 
of killing of the disabled (people with mental and physical disorders) by the Nazis. Even under the broader definition of genocide she adopts, it is unclear under which protected group they fall under. Do they constitute a political group, construed in the broadest possible terms? Or, do they amount to a racial group, given that their destruction, as Rafter notes, was aimed at improving the purity and power of the Aryan stock?

Nonetheless, Rafter executes her empirical task with considerable ease and confidence. Each historical case-study is stripped down to its bare and essential facts, while historical details are selectively chosen and strategically employed to further her main arguments about each of these genocides. This approach clearly aids Rafter's conceptual mission, namely, to compare genocides across multiple dimensions, in order to generate generalized conclusions about what genocides "looks like" as a phenomenon and what they share in common. Some of the important conclusions she draws, in this regard, are the macro dynamics that enable genocide (war and major political upheavals, state failure; ethnic and racial persecution; ideology; colonialism; and impunity); the psychological reasons why individuals are capable of committing genocide (processes of moral disengagement, empathy shutdown and the objectification of victims); and the factors that enable the mobilization of genocidal destruction (the formation of genocidal organizations and the creation of states of exception).

Occasionally, the elegant ideas presented in each chapter are not adequately developed or illustrated through the book's historical case studies, even though this is what Rafter sets herself out to accomplish. For example, Rafter seeks to use the Indonesian genocide to illustrate the emotional dynamics of genocide, which involves, she argues, the framing and reframing of victims' identities by perpetrators, through the creation of social stereotypes or the development of 'us versus them' thinking (Chapter 4). Beyond claiming that this in fact occurred in the case of Indonesia, actual historical evidence for this is missing within Rafter's analysis. A stronger case could have been made by tapping into the wealth of historical analysis, debates and sources that this period of Indonesian history has prompted. To illustrate another example, Rafter suggests the Cambodian genocide usefully demonstrates the micro-level factors that are at play in genocides, namely, the social psychology of genocide perpetrators (Chapter 5). Here, Rafter argues perpetrators are psychologically capable of committing genocide because they undergo a "splitting process," a process that centres on "moral disengagement," "empathy shutdown," and the "objectification of victims." In her historical discussion of the Cambodian genocide, however, she does not concretely demonstrate how, or to what extent, the perpetrators themselves underwent the process which she articulates. In certain parts of the book, therefore, there is disjuncture between the chapters' main conceptual argument and its empirical substantiation. This, in turn, unfortunately diminishes the overall strength of Rafter's main claims, which could have been avoided if the historical analysis was used more directly to engage with, and to buttress, core conceptual arguments.

All throughout, Rafter rightly insists that genocide needs to be understood, first and foremost, as a "crime." Genocide studies, as she writes, is a crowded, multidisciplinary field but it has seldom dealt with genocide as a crime. This is an insightful point; genocide's inherent criminality is easily overlooked, especially when it is subsumed, as it often is, within broader topics such as political conflict, state (in)stability, external interventions or legal prosecutions for human rights violations. Given criminology's core preoccupation with the study of crime, it is particularly wellplaced, Rafter suggests, to interrogate what constitutes the essence of genocide's criminality. This important point is not conceptually pushed far enough by Rafter, however, resulting in her providing a somewhat unsatisfactory answer to the very question she maintains contemporary genocide scholarship has thus far neglected to assess, and which she seeks to address through her book: "What kind of crime is genocide?"

Rafter's answer to this question rests upon unpacking how key concepts in criminologyspecifically, the perpetrators and victims of crimes-figure and feature in the case of genocide. According to Rafter, genocide is a crime whose perpetrators commit their deeds during wars and periods of upheaval; they are likely to mobilize genocidal organizations to help with the killing; they attempt to purify a human group or territory through some sort of "cleansing," be it ethnic, genetic, political, racial, religious or social; and finally, they operate with the confidence that no consequences will follow from their actions. A further aspect of genocide's criminality lies with its 
victims. They tend to be attacked in their own country, where they live alongside their perpetrators and where, sometimes, no prior conflict existed between them and their perpetrators; the victims are often unsuspecting or helpless, lacking "guardians" who could have protected them; and they are negatively labelled by the perpetrator based on race, ethnicity, political views, or status. It is not entirely convincing, however, why these particular characteristics concerning genocide's perpetrators and victims make it a distinct crime in its own right or, as the title of the book suggests, the "crime of all crimes." Arguably, these same characteristics could conceivably apply to other crimes that equally provoke opprobrium for their heinousness, a significant point that Rafter does not herself contemplate. Key examples that immediately come to mind, in this regard, are international terrorism and crimes against humanity.

If Rafter had perhaps engaged a little more with the fact that genocide is not simply any ordinary crime but rather, an "international crime," the significant point she makes about the need to uncover the essence of genocide's criminality could have been pushed a step further. What seems missing from Rafter's take on genocide's essence as a crime are its unique origins and historical development, which saw it being globally condemned as an act that violates the fundamental norms of the international community. An additional line of enquiry, then, to the question Rafter poses - "What kind of crime is genocide?" - lies in the reasons why the act of genocide was specifically fashioned into, and accorded with the special status of, an altogether unique and distinct category of criminal conduct - that of an international crime. Arguably, this is a matter which criminologists, given their interest in how crimes are constructed, would be wellsuited to explore. On balance, however, Rafter's book takes the study of genocide an important step forward. Having shown crucial ways in which the discipline of criminology can have a meaningful conversation and connection with genocide, she had laid further foundations from which other criminologists interested in genocide and other atrocity crimes can fruitfully build upon. 